\title{
Financial Development, Export and Economic Growth in Nigeria
}

\author{
Ismaila Ahmed Sajo, Bin Li \\ Collage of Economics and Trade, Hunan University, Changsha, China \\ Email: absolutechiwi@yahoo.com
}

How to cite this paper: Sajo, I.A. and $\mathrm{Li}$ B. (2017) Financial Development, Export and Economic Growth in Nigeria. Theoretical Economics Letters, 7, 2239-2254. https://doi.org/10.4236/tel.2017.77153

Received: November 14, 2017

Accepted: December 24, 2017

Published: December 27, 2017

Copyright $\odot 2017$ by authors and Scientific Research Publishing Inc. This work is licensed under the Creative Commons Attribution International License (CC BY 4.0).

http://creativecommons.org/licenses/by/4.0/

\begin{abstract}
This paper examines the relationship among Financial Development, Export and Economic growth in Nigeria. The ADF and PP test are used in checking the order of integration of the variables and Johasen co-integration methodology is employed to investigate the long run relationship among the variables. Time series data were collected between 1994 and 2013. The direction of causality between variables is tested by Granger causality test and Ordinary least square (OLS). Econometric techniques were used to estimate the model. Evidence from the study found that exports and transportation development has a positive significant effect and influence in economic growth. While financial development, international trade structure and energy sector has a negative effect on economic growth. The study recommends that government should continue to intensify its efforts in promoting confidence of the public on such sectors, transform energy sectors through adequate and effective regulation and supervision; the reforms in the financial sector should be sustained so as to be able to channel more resources for investment and productive purposes.
\end{abstract}

\section{Keywords}

Financial Development, Export Structure, Economic Growth and Nigeria

\section{Introduction}

The finance is the core of modern economy. Preventing and dissolving from finance risk, and in achieving financial activities safely, efficiently and steadily are the major factors for developing national economy and financial innovation. Finance is the lifeline of modern economy and if there is no finance globalization, there is no economy globalization. Finance globalization has been promoted to enlarge international finance market; multinational trade species and 
the scale make finance appeared to strengthen the international capital function and play an important role on the resource distribution in the world with the communication among nations to increase the technology information development. The development of the finance tends to globalization. Finance globalization is the motor of economy globalization.

Financial structure is the mixture of financial instruments, markets and institutions operating in an economy [1]. Financial system on the other hand, is a set of specialization organization and institutions dealing with the transfer of payments and mediating the follow of savings and investment [2]. Financial development can be defined as improvement in quantity, quality and efficiency of financial Intermediary services [3]. Financial development of any nation is the brain master plan of its economic success. Financial development is considered by many economists to be the paramount importance for output growth. In particular, government restrictions on the banking system (such reserve requirement, interest rate ceiling and directed credit programs) hinder financial development and reduce output growth [4].

It is an undeniable fact that both technological and financial innovations have direct link on economic growth since substantial technological innovations require large investments that are financed by bank, finance and insurance companies. More ever, it is nostalgic to recall that the financial system in Nigeria was underdeveloped and highly regulated during 1970s and 1980s. For instance, interest rates and imposed credit ceilings were common; similarly, bank ownership and management were seriously manipulated by the government. That is with a view to making it easy for the government to secure the financial resources at a reduced rate and control the operational and managerial capabilities of the banking institutions.

With the support of international institutions like the World Bank and International monetary fund, in 1986 Nigeria started liberalizing the financial sector of the economy through privatization and commercialization with a view to making their financial sector more efficient. This has been going on and on, with the most recent and exciting one in 2010. The countries with large banks and more active stock market grow faster over subsequent decades even after controlling for many other factors underlying growth. Industries and firms that rely heavily on external financing grow disproportionately faster in countries with well-developed banks and securities market than countries with poorly developed financial systems.

Economic growth can be defined as an increase in value of goods and services produced in a country. Growth implies an increase in real GNP per unit of labor input. This refers to changes in labor productivity over time. Economic Growth is conventionally measured as the rate of increase in Gross Domestic Product (GDP). Growth is usually calculated in real terms (netting out the effect of inflation on the price of the goods and services product). Growth improved the standard of living of the people in that particular country. Economic growth is measured by the Gross Domestic Product (GDP) in Nigeria. 
Money or traded in a market system over certain periods. This indicates that trade is an essential aspect of Economic growth. We also in our analysis discovered that in the contribution of the Export, Transport sectors as the key to national GDP exportation of crude oil, cash crops, aviation industry and road transportation made the most contribution [5]. This makes the industry the gateway to any aspiring to develop, enabling globalization, trade facilitation and tourism development. It is very crucial in promotion of foreign direct investment (FDI). One can therefore say that the industry is crucial to the growth of the economy and national development. The emerging economies grow, their demand for air transportation will grow as their citizens become more financially empowered with increase disposable income [6].

EXPORT can be defined as surplus goods and services of a country that are sent to other countries in the world for sale. Export growth may lead to increase scope of economies of scale. Economies of scale result from enlargement of market size due to efficient allocation of resources and competitiveness of exporting firms. Increased export also positively impact on aggregate output by relaxing foreign exchange constraint. In a similar vein, export expansion leads to growth through the stimulation of technical change and investment or by demand spill over into other sectors of the economy, export expansion can also accelerate the growth process by providing foreign exchange, which is required to produce capital goods and other intermediate goods that are needed to keep industries running. Increased international trade can generate economic growth by facilitating the diffusion of knowledge and technology from the direct import of high-tech goods [7] [8] [9]. Trades facilitate integration with the sources of innovation and enhance gains from foreign direct investment. By increase the size of market, trade openness allow economies to better capture of potential benefits of increasing return to scale and economies of specialization.

Ideally every country should export more goods and services than it import goods and service. This differs on the natural resources, technology and labour force. Nigeria is Africa's most populous country with a population of over 170 million people. It is one of the largest oil producers in the continent creating huge inflows of foreign income. Without question it holds enormous commercial potential as recent administrations have focused on developing the non-oil economy and tackling corruption. The explosion of the industry such as the mobile telecoms market and the unparalleled success of foreign companies such as South Africa's MTN have also demonstrated that the potential can be turned into reality. Despite persistent problems corruption and bureaucracy the international business community increasingly sees Nigeria as the central driver of a vast African market that remains the last under-developed commercial market in the world.

\section{Nigeria's Export Performance}

Nigeria's economy was mainly an agrarian economy which the majority part of its foreign exchange comes from the sales of cash crops such as cocoa, ground- 
nut, coffee, cotton, solid minerals and palm produce. Due to the oil boom of 1970s, crude oil then took over from agricultural as the major foreign exchange earner to the country it to $96.8 \%$, while by 2000 ; it got to $99 \%$. The government made efforts to restore the non-oil sector of the economy during the structural Adjustment Programme period. Despite all the measure that were put in place, the performance of the non-oil export sector has remained encouraging as crude oil still remains the major Nigeria's export. Furthermore, on the trends of the structure of Nigerian economy, her trade exports makes it unlikely that the country will be able to take the advantage of increased liberalization and openness of the economy to achieve trade induced growth.

\section{Contribution of Exports to Economic Growth}

Exports positively contribute to economic growth in Nigeria through various ways:

1) Exports expansion benefit from international market also allows greater capacity utilization exploiting increasing foreign demand in world markets.

2) An increase in exports could promote specialization in the production of export commodities that in turn may increase the productivity of the export sector.

3) Export may also give access to advanced technological improvement in the economy due to foreign market competition.

4) Export expansion may result in efficient resource allocation since it brings incentives for domestic resource allocation closer to international opportunity costs.

5) Exports that are based on comparative advantage would allow the exploitation of economies of scale that are external in the non-export sector, but internal to the overall economy.

Economic Globalization has two dimensions: actual economic flows and restrictions to trade and capital. The sub-index on actual economic flows includes data on trade, FDI, and portfolio investment. The sub-index on restrictions takes into account hidden import barriers, mean tariff rates, taxes on international trade such as a share of current revenue, and an index of capital controls. Dos Santos believed that, unequal exchange led to the development of dependency relationship where third world has their economies conditioned by the growth and expansion of another economy. Nigeria as an example experienced dependent economy which is considered among the factors responsible for economic slow growth rate. Globalization imposed a dependent capitalist social system and western values in the forms of industrialism, market principle and institutions on Nigeria. Nigeria has been experiencing disappointing performance in terms of growth in GDP and the general development of her economy. As a result there is no improvement in the reduction of poverty. In the last decades, the global economy suggest a challenge; the utilization of the opportunity engineered by globalization while at the same time managing the problem and ten- 
sion it poses, for developing countries like Nigeria. Rather than strengthening the economy, globalization seeks to retrench it, thus Nigeria enters the global market at a competitive disadvantage as a largely mono-product economy with weak currency, shrinking indigenous industrial space, mounting debt profile, corruption-infested political and economic climate.

Energy is an extremely important source of economic growth as it feeds in to other productive economic activities. In Nigeria the energy sector perform beyond expectation due to Inability to generate enough energy power supply to meet local demand as well as help propel industrial, economic growth and development. In Nigeria the energy sector cannot influence the economic growth.

\section{Literature Review}

There are so many literatures that examine the relationship among financial development, export and GDP growth; literature on Nigeria is limited.

On the determinant of economic development and economic growth is pronunciation. According to the traditional textbook theory that draws neoclassical model, output growth is determined largely by a country's available resources such as capital and factor and technological change is determined exogenously [10]. In this framework, the so called new growth theory developed recently, by contrast, emphasizes technological change as endogenous phenomenon [11]. In line with Keynesian oriented framework, endogenous growth model allow for the role of foreign trade on domestic growth. In those models, export open up opportunities for increase specialization, which in turn leads to higher productivity growth through learning by doing [12]. Some other channel which export induced specialization promotes economic growth stems from the Ricardian prospective that some activities might promotes growth more than others due to either supply-side factors for example, (technological requirements) or demand-side factors e.g. (price elastic ties). As a result, what a country specializes in has implications for its growth performance. On the effect of exports on growth e.g. stresses the so-called natural resources curse, which explains the relatively poor economic performance of countries with an natural resources [13]. The rational for this observation include volatility of revenue from natural resources, government mismanagement and unstable institutions or corrupt. A cross country evidence to confirm that natural resources curse is less severe in countries with better institutional environment and less restrictive trade policies [14].

The development of the financial sector can also reduce poverty. The provision of bank accounts can enable the poor (low-income earner) to accumulate funds in a secure place for a period time so as to finance a large, anticipated future expenditure. The bank account can also improve access to financial services like remittances or insurance. The mobilization of savings from the poor will also create funds available for tending. The availability of credit will strengthen in 
new and better tools, equipment, or fertilizers. The availability of credit has assisted in the expansion of small business leading to increase in income and employment generation. This has made the financial sector to facilitate transactions between local and international business concerns which enhance value creation [15].

A well-developed financial system enhances investment by identifying and funding good business opportunities, mobilizing savings, enabling trading, hedging and diversifying risk, and facilitating the exchange of goods and services. The direct effect of these functions will lead to more efficient allocation of resources, rapid accumulation of physical and human capital, faster technological progress and economic growth. An efficient financial system is one of the foundations for building sustained economic growth and an open, vibrant economic system [16]. The very important link between financial development and growth, but also sounds a note of caution that not all types of financial deepening is beneficial for the economy. In the case of Turkey, financial deepening meant that savings left the provinces, depriving the real industry of credit needed for investment projects. As such, it may not be hard to imagine that if the banking sector was functioning efficiently during this period, then financial deepening may have contributed to economic growth in the provinces, as opposed to taking them into a serious crisis. They concluded that it is important to note that financial deepening measured in terms of the ownership of banks may distort incentives leading to an underdevelopment of growth of both the public and the private banks. Therefore, financial sector deepening in terms of the public and private banks could be analyzed separately before making firm conclusions about the negative relationship between financial development growth and economic growth. Hence, it can then be hypothesized that financial development can trigger economic growth through the energy link. Thus, it can be consistently said that financial development is an engine of economic growth. On the other issue is the financial crises literature which finds a negative effect of financial development on economic growth. This literature posits that increased monetary aggregates can cause unduly large expansion of credit. This may lead to over-lending, which might increase the rate of moral hazard and adverse selection, weaken proper monitoring of credit facilities and the likes, which will eventually have negative effects on economic growth.

Economic reforms generally are predicated upon the need for getting policy incentives right and for the reorientation and the restructuring of the key implementation institutions in order to attain an efficient and effective state. Economic reforms therefore focus principally on repositioning financial sector institutions and markets using various policy measures. Although there are divergent opinion amongst economists and researchers regarding the role of the financial system in economic growth and development, growth literature show that many scholars believed that finance play an insignificant role in economic growth and development of any nation [17] [18]. Financial sector reform and credit supply to the Nigerian agricultural sector before and after the reforms for 
the period covering 1978 to 2009 . There result indicated an exponentially increasing trend of agricultural credit supply in the economy after the reform began [19]. Solomon and Dayo using the OLS technique examined community/microfinance banking and sectorial growth for the period 1992 to 2008. The study reveal that a sector analysis using OLS show that while loan and advances from micro finance/commercial banks positively influenced output of manufacturing, building and construction and mining and quarrying sectors, the same could not be established for the agricultural sector [20].

David Hume, foreign trade as the engine of economic growth, political and economic development. Adam Smith on the benefits of free trade coherently argues in the wealth nations and theory of absolute advantage has to offer [21]. David Ricardo's theory of comparative advantage, while providing the freedom to trade at a fixed target and become the UK's economic policy. After Ricardo and Smith. Mill believed that international trade leads to greater efficiency of production factors at international level and consider it as foreign direct advantage. He believes that the expansion of international trade good and services markets is leading to improve the manufacturing process [22].

Jenkins and Katircoioglu investigate the long run relationship between financial development, international trade, financial development and economic growth are co-integrated and the Granger causality test shows that real income contribute to the growth of financial development and international trade. Financial development is key as one of the most important sources of comparative advantage [23]. Some studies conducted by some scholars to estimate the average influence of the determinants of economic growth, and World Bank find that 'higher levels of financial development are significantly and robustly correlated with faster current and future rates of economic growth, physical capital accumulation and economic efficiency improvements [24] [25]. The empirical evidence between financial development and economic growth shows that in the work of (King and Levine 1993a). Huge volume of financial development is required, which affect significantly and strongly correlated with social infrastructure, gross physical capital formation and growth. King and Levine use IMF data and various financial indicators to conclude there is a positive relationship between financial indicators and growth, and that financial development is robustly correlated with subsequent rates of growth, capital accumulation, and economic efficiency. They correctly emphasize that policies that alter the efficiency of financial intermediation exert a first order influence on growth [26]. In this line of research, Robinson argued that the finance does not have the potency to exert a causal impact on growth rather; financial development follows economic growth due largely from the consistent rise in demand for financial services [27].

\section{Empirical Literature}

The contribution of financial development, export growth and economic growth has been tested by different economists using different econometric techniques: Mohammed and Sidiropoulos investigated the effect of financial development 
on economic performance in Sudan from 1970 to 2004. The study estimated the short-run and long-run relationship between financial development and economic growth using the autoregressive distributed lag (ARDL) model to co-integration analysis. Their empirical results indicated a weak relationship between financial development and economic growth in Sudan due to the inefficient allocation of resources by banks, the absence of an appropriate investment climate required to foster significant private investment in order to promote growth in the long run, and the poor quality of bank credit allocation [28].

A causality approach examines that there is a relationship between exports and economic growth in Nigeria. Using Johansens multivariate co-integration technique. The result shows that there is stationary relationship between exports and gross domestic product (GDP). There is feedback causality between exports and economic growth. Odularu used Harrod-Domar theory and solow's theory of economic growth used Ordinary Least Square regression and cobb-douglas production function were employed to test the impact of crude oil on Nigeria economic performance. The result shows that crude oil production contributed to economic growth but have no significant improvement on economy growth of Nigeria [29].

Rahmadi (2011), examine the exports and economic growth nexus in Indonesia employing vector autoregressive (VAR) model. The findings indicate the significance of both exports and economic growth to economy of Indonesia as indicated in GIRF analysis. It was concluded that exports and economic growth exhibits bidirectional causal structure, which is Export Led Growth in long-run and Growth Led Export in short-run both financial development measures are negatively correlated with the growth of per capita GDP [30]. However, only private sector credit share of GDP shows marginal significance. On including the squared terms, which is how we elect to gauge the influence of thresholds, there is a reversal of signs of coefficients although insignificant across the board. Precisely, what we glean is evidence in favour of a threshold of some sort namely that financial advancement at inception does not seem to matter much for growth but as a critical level of FD is reached and eventually exceeded their appears to be a positive, albeit statistically weigh less, growth effect. Impasse, we note that money growth and inflation are negatively associated with economic growth but only the former appears to be precisely estimated. Government spending turns up positive estimates across FD measures but these are devoid of significance at the conventional levels. Furthermore, a peep at column 3 seems to suggest that the positive growth influence of FD could also be achieved with an index which summarizes the information in both FD metrics, although this is equally not significant. (Financial development and economic growth in Nigeria: Evidence from threshold modeling).

\section{Problems}

The link between the financial sector and the growth of the economy has been 
weak. The real sector of the economy, most especially the high priority sectors which are also said to be economic growth drivers are not effectively and efficiently serviced by the financial sector. Nigeria will continue to have problems with its energy sector because of its inability to develop a long-term vision that links energy access with industrial transformation. Most of the textile industries in Nigeria have closed down due to lack of access to sufficient energy The country produces more than $4000 \mathrm{MW}$ which is very low for consumption but needs 20,000 if it is to achieve its development goals.

There is also problem with global economy crises which is affected Nigerian economy as well and declining in real output growth and weakened financial systems, precipitated takeover and bankruptcy, which in turn led to loss of jobs, loss of confidence in financial market, leading to inability of the financial houses to carry out their intermediation role in the economy. The Nigerian economy witnesses the collapse of commodity prices, especially the fall in oil revenue, reducing the government ability to carry out some of its financial obligations.

Currently Nigeria is faced with so many problems affecting the international trade which is the buying and selling of goods and services with other countries". Rugman and Simon (2009) also give reasons for trade barriers which effectively raise the cost of imported goods and make them more expensive to local buyers; this is also a problem of international trade.

\section{Source of Data and Method of Analysis}

The purpose of this study is to examine the relationship among Financial Development, Export and Economic growth in Nigeria. The data were used in this study were sourced from the Central Bank of Nigeria (CBN), Central Bank of Nigeria Publications and Statistical Bulletin Volume 18, 2007, National Bureau of statistics (NBS), annual publications, World Bank, other sources of data used were Economic journals, Textbooks, Internet, Published articles in the subject matter. The data used in this paper are annual figure for the period 1994-2013. Contain variables: Gross domestic product (GDP), Financial structure (FIN STR), Export (X) Transportation, Energy, Cons. The model is represented by an algebraic equation. The work drive consistent, unbiased and efficient estimators of the structural equation, the hypothesis was tested using ordinary least square (OLS) regression technique, and test the significance of the policy variables; statistically test such as Unit root test, F-test and t-test.

\section{Model Specification}

The study examines the relationship among Financial Development, Export structure and Economic growth in Nigeria by using time series data econometric methodology.

$$
\text { Ln GDP }=\mathrm{f}(\text { Fin }+ \text { str }+ \text { Fin } \times \text { str }+ \text { Tran }+ \text { Ene }) \text { Et }
$$

This can be econometrically modeled thus:

$$
\text { Ln GDP }=\beta_{0}+\beta_{1} \text { lNFin }+\beta_{2} \operatorname{Str}+\beta_{3} \text { Fin } \times \text { Str }+\beta_{4} \text { Tran }+\beta_{5} \text { Ene }+ \text { Et }
$$


where:

$\beta_{1} \cdots \beta_{5}=$ parameters estimation

$\mathrm{GDP}=$ represent the real gross domestic product

Fin $=$ represent Financial Structure Development

Str $(\mathrm{X})=$ Structure of international Trade

Fin $\times$ Str $=$ Financial Structure Development $\times$ Structure of international Trade

Tran $=$ Transportation

Ene $=$ Energy

$\mathrm{ET}=$ is the error term assumed to be normally and independently distributed with zero mean and constant variance which captured all the explanatory variables which influence economic growth but not capture the model.

Where:

\subsection{Unit Root Test}

The co-integration test between the examined variables requires initially a test for the existence of a unit root for each individual time series and especially for financial development, export and economic growth. Prior to any empirical analysis first the order of integration of the variables has to be investigated. In our study, ADF-fisher and ADF first order differential test and unit root test are used to test whether series are stationary. Null hypothesis for ADF-fisher and $\mathrm{ADF}$ first order differential test is that series has unit root test. If series is non-stationary at level, the first difference of the series should be taken in order to make the series stationary series level is donated by Table $1(0)$ and unit root is donated by 1 (1).

\subsection{Co-Integration Test}

If all variables have the same order of integration, the next step is to use co-integration analysis to investigate the long-run equilibrium relationship among variables. Johansen approach is employed to test the co-integration. Johansen test help to identify the long run relationship between variables; there should be at least one co-integrating vector in order to have co-integration among the variables [31]. Below are the co-integrated Table 2 and Table 3.

Pairwise Granger to determine whether there is granger causality between financial development, Export and economic growth in Nigeria, causality test should be applied to find the direction of long-run relationship among variables. Granger causality test are run by retaining the Vector Error Correction (VEC) framework when there is co-integration relationship. Below are the Table 4 and Table 5.

Estimated method adopt in this study is the ordinary least square (OLS) consisting of R-square $\left(R^{2}\right)$, F-statistic and T-test. The R-square $\left(R^{2}\right)$ is concerned with overall explanatory power of the regression analysis, the F-statistic is used to test overall significant of the regression analysis and T-test is used to test the significant contribution of independent variables on the dependent. 
Table 1. Unit root test.

\begin{tabular}{ccc}
\hline \multirow{2}{*}{ variables } & \multicolumn{2}{c}{ First order differential } \\
\cline { 2 - 3 } & ADF-fisher & Fisher-ADF \\
\hline GDP & $-4.502931^{* *}(0.0114)$ & $-6.7873^{* * *}(0.0001)$ \\
FIN & $-4.442559^{* * *}(0.0127)$ & $-5.3827^{* * *}(0.0014)$ \\
STR & $-4.385072^{* *}(0.0152)$ & $-5.0838^{* * *}(0.0029)$ \\
TRANS & $-3.859828^{* *}(0.0404)$ & $-4.9595^{* * *}(0.0040)$ \\
ENE & $-5.571559^{* *}(0.0013)$ & \\
\hline
\end{tabular}

Source: Author's Computation. ${ }^{* * *} 1 \%,{ }^{* *} 5 \%,{ }^{\star} 10 \%$.

Table 2. Co-integration test-unrestricted co-integration rank test (Trace).

\begin{tabular}{|c|c|c|c|c|}
\hline $\begin{array}{l}\text { Hypothesized } \\
\text { No. of CE (s) }\end{array}$ & Eigenvalue & $\begin{array}{c}\text { Trace } \\
\text { Statistics }\end{array}$ & $\begin{array}{l}0.05 \\
\text { Critical value }\end{array}$ & $\operatorname{Prob}^{* * *}$ \\
\hline None ${ }^{*}$ & 0.988484 & 186.0987 & 88.80380 & 0.0000 \\
\hline At most $1^{*}$ & 0.964485 & 105.7467 & 63.87610 & 0.0000 \\
\hline At most $2^{*}$ & 0.656337 & 45.66650 & 42.91525 & 0.0259 \\
\hline At most $3^{*}$ & 0.537682 & 26.44080 & 25.87211 & 0.0425 \\
\hline At most $4^{*}$ & 0.502137 & 12.55374 & 12.51798 & 0.0493 \\
\hline
\end{tabular}

Source: Author's Computation. Development which cannot support the GDP Growth in Nigeria. The Structure of international Trade is also Trace test indicates 5 co-intergrating eqn (s) at 0.05 level. ${ }^{*}$ donotes rejection of the hypothesis at 0.05 level; ${ }^{\star *}$ Mackinnon-Haug-Michelis (1999) $p$-values.

Table 3. Co-integration test-unrestricted co-integration rank test (maximum eigenvalue).

\begin{tabular}{|c|c|c|c|c|}
\hline $\begin{array}{l}\text { Hypothesized } \\
\text { No. of CE(s) }\end{array}$ & Eigenvalue & $\begin{array}{c}\text { Trace } \\
\text { Statistics }\end{array}$ & $\begin{array}{l}0.05 \\
\text { Critical value }\end{array}$ & Prob $^{* * *}$ \\
\hline None ${ }^{*}$ & 0.988484 & 80.35194 & 38.33101 & 0.0000 \\
\hline At most $1^{\star}$ & 0.964485 & 60.08022 & 32.11832 & 0.0000 \\
\hline At most $2^{\star}$ & 0.656337 & 19.22570 & 25.82321 & 0.2903 \\
\hline At most $3^{\star}$ & 0.537682 & 13.88706 & 19.38704 & 0.2618 \\
\hline At most $4^{\star}$ & 0.502137 & 12.55374 & 12.51798 & 0.0493 \\
\hline
\end{tabular}

Source: Author's Computation. Max-eigenvalue test indicates 2 cointergrating eqn (s) at the 0.05 level. * denotes rejection of the hypothesis at the 0.05 level; ${ }^{*}$ Mackinnon-Haug-Michelis (1999) $p$-values.

Table 4. Pairwise granger causality tests.

\begin{tabular}{cccc}
\hline Null Hypothesis & Obs & F-statistic & Prob. \\
\hline FIN does not Granger Cause GDP & 20 & 3.70812 & 0.0721 \\
STR does not Granger Cause GDP & 20 & 4.52994 & 0.0842 \\
TRANS does not Granger Cause GDP & 20 & 4.38306 & 0.0435 \\
ENE does not Granger GDP & 20 & 4.60758 & 0.0820 \\
\hline
\end{tabular}

Source: Author's computation. 
Table 5. OLS regression.

\begin{tabular}{cccc}
\hline Variables & Coef. & Std. Err. & $P$ \\
\hline FIN & -1.570279 & 0.4266513 & 0.000 \\
STR & -0.9112262 & 0.2446764 & 0.753 \\
X & 0.3553206 & 0.0874644 & 0.001 \\
TRANS & 0.7766102 & 0.0801412 & 0.024 \\
ENE & -2.927089 & 4.688294 & 0.542 \\
CONS & -19.07662 & 31.87666 & 0.001 \\
OBS & & 20 & \\
F-test & & $0.53(0.0000)$ & \\
$\mathrm{R}^{2}$ & & 0.9368 & \\
Adj-R & & 0.9143 & \\
\hline
\end{tabular}

Source: Author's Computation. F-test: is any statistical test in which the test statistic has an F-distribution under the null hypothesis. It is most often used when comparing statistical models that have been fit to a data set, in order to identify the model that best fits the population from which the data were sampled. Exact F-tests mainly arise when the models have been fit to the data using least squares.

$$
\begin{aligned}
\mathrm{GDP}= & -19.07662-1.570279(\mathrm{FIN})-0.9112262(\mathrm{STR})+0.3553206(\mathrm{X}) \\
& +0.7766102(\text { TRANS })-2.927089(\mathrm{ENE})
\end{aligned}
$$

\section{Empirical Results}

The estimation of production function is summarized as follows:

$$
\begin{aligned}
\mathrm{Y}= & -19.07662-1.570279 \mathrm{FIN}-0.9112262 \mathrm{STR}+0.3553206 \mathrm{X} \\
& +0.7766102 \mathrm{TRANS}-2.927089 \mathrm{ENE}
\end{aligned}
$$

$\mathrm{R}^{2}=0.9368$

Adjusted $\mathrm{R}^{2}=0.9143$

The study used time series data from 1994-2013 to analyze the relationship among Financial Development, Export structure and Economic growth in Nigeria. The coefficient of multiple determination $\mathrm{R}^{2}$; stood at $0.94(94 \%)$ and 0.91 (91\%) which means the explanatory variables: Financial Development and Export structure accounted for $94 \%$ and $91 \%$ of the total variations in the dependent variables, Gross Domestic product (GDP); which is a good fit.

The production function exhibits satisfactory results in term of positive signs on Export and Transportation sector (Aviation) are statistically significant of explanatory variables and negative sign on Financial Structure Development $x$ Structure of international Tradenegative which cannot influence the GDP Growth. The energy sector has negative effect and con not influences the GDP Growth. It means if Export and Transportation sector (Aviation) has positive effect, the GDP will be better in Nigeria. The major export commodity is crude oil and the leading sector is now the petroleum sector. In Nigeria, crude oil is the major export because of the large revenue it generates. Nigeria's economy was 
mainly an agrarian economy which the majority part of its foreign exchange comes from the sales of cash crops while oil then took over from agricultural as the major foreign exchange earner to the country it to $96.8 \%$, while by 2000 ; it got to 99\% (Kareem 2004). According to the World Trade Organization (2010), diversification of countries export base increases local Production, employment, income and economic growth [32].

Transportation is a critical factor in the economic growth and development. It is a wealth creating industry on its own inadequate transportation limits a nation's ability to utilize its natural resources, distributes foods and other finished goods; integrate the manufacturing and agriculture sectors and supply education, medical and other infrastructural facilities. There is the need therefore to maintain and improve the existing transportation and build new infrastructures for a national wealth. The national wealth is the growth domestic products (GDP) which is an indicator or measures of the rate of economic growth. While Financial Structure Development, Structure of international Trade and energy sector has a negative effect which cannot influence the Economic Growth in Nigeria. This could be due to the economy recession in Nigeria as a result of fallen cost of oil in international market and destruction of oil pipeline by militancy in the production places. It brings shortest of foreign currency in the economy less USD in the country and demands are high, it also creates inflation in the economy. This is in line with Boyereau-Debray (2003) study on Chinese financial development and growth, which finds that credit extended by the banking sector at the state level, has a negative impact on provincial economic growth., The structure of international trade is also negative to GDP Growth due to activities of informal sector without the knowledge of Nigeria government and no official records are keeping or recorded by the government, the transactional record can be trace in other countries but in Nigeria the records are zero non recorded [33]. A nation not participating in international trade is at risk of a slow pace of economic development due to the cogent fact that a country cannot be fully endowed with all the resources essential to be utilized for sustainable economic development. Energy sector (power generating energy) has negative effect. Nigeria will continue to have problems with its energy sector because of its inability to develop a long-term vision that links energy access with industrial transformation. The country produces more than $4000 \mathrm{MW}$ but needs 20,000 if it is to achieve its development goals, currently it has a 5900 MW capacity but this cannot be fulfilled because of lack of maintenance and infrastructure in decline. Nigeria requires $40,000 \mathrm{Mw}$ of power to meet the energy needs of its over 170 million population [34].

\section{Conclusions}

The paper has examined the relationship between financial development, export structure and economic growth in Nigeria. Our empirical results show the positive effect on export and transportation sector which influence the economic 
growth while there is negative impact on financial development, structure of international trade and energy sectors. Energy is an extremely import source of economic growth as it feeds into other productive economic activities. To capture this time series data have been collected from 1994-2013 period. The Augmented Dickey-fuller, unit root test shows that all variables were stationary. Johnsen co-integration reveals co-integration test. The result of the study has been found, that there is a positive relationship between export and transportation. It has a significant impact on GDP effect which influences the economic growth and negative effect on financial development. Structure of international trade and energy sector cannot influence the GDP in Nigeria within the study period, and Granger causality shows all the exogenous variables cause GDP, while GDP cause other variables as they indicated significance at 5\% level. The result also shows that the value of the $\mathrm{R}$ square is 0.94 which simply indicated around $94 \%$ variations. Again, the F test that shows the overall statistical significance of the whole model shows a value that is found to be statistically significant.

The major challenge to the Nigerian financial sector development is how to engender healthy competition in addition to enhancing investments so as to achieve a desired economic growth and maintain its position as one of the emerging economies.

\section{Recommendation}

Based on the findings of this study, it is important to provide a set of policy recommendation that would be applicable to the Nigerian economy.

1) Government should establish an institution that will ensure that the multinational companies that socially responsible to their host company and also Government should employ favorable policies (like lower tax and tax holidays for new investors) that will promote the inflow of international capital and foreign investment, so as to enhance the production capacity of the nation.

2) Government should improve on fighting corruption in financial sector and other sectors, arrest and prosecute corrupt public office holders.

3) Nigerian trade performance should be improved through economic diversification so as to reduce much emphasis on oil export and availability of funds private sector at Competitive interest rate in order to produce internationally competitive products should be encouraged.

4) Government should continue to intensify its efforts at promoting confidence of the public on such sectors, transform energy sectors through adequate and effective regulation and supervision, the reforms in the financial sector should be sustained so as to be able to channel more resources for investment and productive purposes.

5) That government's policy aimed at increasing growth should also work more on developing the financial system, which is a major factor in determining growth. 


\section{Acknowledgements}

I wish to acknowledge my supervisor Professor LI BIN, all lecturers in department of Economic and Trade, my colleague Mr. Lito for their immense contribution to the success of this study.

\section{References}

[1] Goldsmith, R.N. (1969) Financial Structure and Development. Yale University Press, New Haven.

[2] Abebefe, H.A. (1995) The Structure of Nigeria's External Trade. Central Bank of Nigeria Bullion, October/December, 19(4)

[3] Calderon, C.A. (2003) The Direction of Causality Between Financial Development and Economic Growth. Journal of Development Economics, 72, 321-334.

[4] Ronald McKinnon and Shaw (1973) World Economy Financial Repression. 1.

[5] Aerospace Global Report, 2011.

[6] Ladele (2015) Air Transportation Development and Economic Growth in Nigeria. Journal of Economic and Sustainable Development, 6.

[7] Barro, R.J. and Sala-i-martin, X (1997) Technological Diffusion, Convergence, and Growth. Journal of Economic Growth, 2, 2-26s. https://doi.org/10.1023/A:1009746629269

[8] Baldwin, R.E., Bracoier, H. and Forslid, R. (2005) Multinational, Endogenous Growth, Technological Spillovers: Theory and Evidence. Review of International Economics, 13, 954-963. https://doi.org/10.1111/j.1467-9396.2005.00546.x

[9] Almedida, R. and Fernades, A. (2008) Openness and Technological Innovations in Developing Countries: Evidence from Firm Level Surveys. The Journal of Development Studies, 44, 701-727. https://doi.org/10.1080/00220380802009217

[10] Solow, R. (1990) A Contribution to the Theory of Economic Growth. Quarterly Journal of Economics, 70, 65-94. https://doi.org/10.2307/1884513

[11] Romer, P.M (1990) Endogenous Technological Change. Journal of Political Economy, 98, 71-102.

[12] Kaldor, N. (1996) Causes of the Slow Trade Rate of Economic Growth of United Kingdom. Cambridge University Press, Cambridge, MA.

[13] Warner, J. and Sachs (1995) Natural Resources Abundance and Economic Growth. NBER Working Parper W5398, Cambridge, MA.

[14] Van der ploeg, F. and Arezki (2010) Trade Policies, Institutions and the Natural Resources Curse. Applied Economics Letters, 17, 1443-1451. https://doi.org/10.1080/13504850903035881

[15] Uche, R.U. (2008) The Role of Banks, Insurance and Microfinance Institutions in National Development. The Nigerian Accountant, 41.

[16] Anyanwu, C.M. (2010) An Overview of Current Banking Sector Reforms and the Real Sector of Nigeria Economy. Economic and Financial Review, 48, 31-57.

[17] Wijnbergen, S.V. (1983) Interest Rate Management in LDCs. Journal of Monetary Economics, 12, 433-452. https://doi.org/10.1016/0304-3932(83)90063-6

[18] Rousseau, P.L. and Wachtel, P. (2005) Economic Growth and Financial Depth: Is the Relationship Extinct Already? Discussion Paper.

[19] Onoja, A.O., Onu, M.E. and Ajodo, O.S. (2011) Contributions of Financial Sectors 
Reforms and Credit Supply to Nigerian Agricultural Sector (1978-2009). Journal of Applied Statistic, 2.

[20] Solomon, A.O. and Dayo, B.O. (2011) Community/Microfinance Banking and Sectoral Growth: An Empirical Lesson from Nigeria. Journal of Economic Theory, 5, 21-34.

[21] Adam Smith (1776) The Wealth of Nations. W. strahan and T. Cadell, London.

[22] Singer, H.W. (1990) U.S. Foreign Investment in Underdevelopment Area. American Economic Review, Papers and Proceedings, No. 4.

[23] Jenkins, H.P. and Katircioglu, S.T. (2010) The Bounds Test Approach for Co-Integration and Causality between Financial Development, International Trade and Economic Growth: The Case of Cyprus. Applied Economics, 43, 1699-1707. https://doi.org/10.1080/00036840701721661

[24] Gelb, A.H. (1989) Financial Policies, Growth and Efficiency Policy Planning and Research. Working Papers, No. 202, World Bank.

[25] World Bank (1989) World Development Report. Oxford University Press, Oxford.

[26] King, R.G. and Levine, R. (1993) Financial and Growth: Schumpeter Might Be Right. Quarterly Journal of Economics, 108, 717-737. https://doi.org/10.2307/2118406

[27] Robinson, J. (1952) The Rate of Interest and Other Easys. Macmillan, London.

[28] Mohammed, S.E. and Sidiropoulos, M. (2006) Finance-Growth Nexus in Sudan: Empirical Assessment Based on an Application of the ARDL Model.

[29] Odularu, G.O. (2008) Crude Oil and Nigerian Economic Performance.

[30] Rahmadi, R. (2011) Exports and Economic Growth in Indonesian. A Causality Approach Based on Multi-Vitiate Error Correction Model. Journal of International Development and Cooperation, 17, 53-73.

[31] Johasen, S. (1988) Statistical Analysis of Co-Integration Vectors. Journal of Economics Dynamics and Control, 12, 231-254. https://doi.org/10.1016/0165-1889(88)90041-3

[32] World Trade Organisation (2010) 10 Benefits of the WTO Trading System.

[33] Boyereau-Debray, G. (2003) Financial Intermediation and Growth-Chinese Style. Policy Research Working Paper 3027, the World Bank.

[34] Kandeh Yumkella (2012) 3SMedia, August 29 in Electrification News. 